$\mathcal{H a l}: 1-9$

\title{
HUBUNGAN STATUS GIZI SISWI SMP DI PEDESAAN DAN PERKOTAAN TERHADAP POLA SIKLUS MENSTRUASI
}

\section{RELATIONSHIP NUTRITIONAL STATUS OF SMP STUDENTS AT RURAL AND URBAN TOWARD MENSTRUAL CYCLES PATTERN}

\author{
Anggi Nadra Hanum Siregar ${ }^{1)}$, Dewi Karlina Rusly ${ }^{2)}$, Rizarullah $^{2)}$ \\ ${ }_{1}^{1}$ Mahasiswa Fakultas Kedokteran, Universitas Abulyatama, Jl. Blangbintang Lama, Kuta Baro, 24415 \\ 2 Dosen Fakultas Kedokteran, Universitas Abulyatama, Jl. Blangbintang Lama, Kuta Baro, 24415 \\ Email: angginadrahanum22@gmail.com
}

\begin{abstract}
Abstrak. Masa remaja merupakan masa transisi atau peralihan dari masa anak-anak menuju dewasa yang ditandai adanya perubahan fisik, psikis dan psikososial. Pada remaja putri, pubertas ditandai dengan permulaan menstruasi (menarche). Pada remaja putri dibutuhkan status gizi yang baik dalam membantu pertumbuhan remaja termasuk keteraturan siklus menstruasi. Remaja putri yang mengalami asupan gizi kurang atau lebih dapat menyebabkan gangguan fungsi reproduksi dan berdampak pada gangguan menstruasi. Tujuan penelitian untuk mengetahui hubungan status gizi dengan siklus menstruasi pada remaja putri di SMP perkotaan dan pedesaan. Desain penelitian yaitu metode koleratif dengan rancangan cross sectional, populasi yaitu semua remaja putri yang memenuhi kriteria inklusi. Sampel penelitian ini 120 responden termasuk 60 responden daerah pedesaan dan 60 responden dari daerah perkotaan yang didapat dengan menggunakan teknik purposive sampling. Instrumen yang digunakan yaitu kuesioner siklus menstruasi dan lembar obeservasi hasil pengukuran berat badan dan tinggi badan yang dilakukan. Hasil uji statistik menggunakan uji Chi Square pada tingkat kemaknaan 95\% $(\alpha \leq 0,05)$, kemudian diperoleh dipedesaan dengan nilai $p=0.401$ sedangkan diperkotaan dengan nilai $p=0.203$. Ini berarti bahwa nilai $p>\alpha(0,05)$. Dengan demikian bahwa tidak terdapat hubungan yang bermakna antara status gizi dengan siklus menstruasi pada remaja putri di remaja putri di SMP perkotaan dan pedesaan. Dan juga tidak ada perbedaan secara signifikan semua variabel. Saran untuk remaja putri agar lebih menjaga status gizi dan memelihara kesehatan reproduksi mereka agar siklus menstruasi mereka menjadi teratur.
\end{abstract}

Kata Kunci: Status Gizi, Siklus Menstruasi, Remaja Putri.

Abstract. Adolescence is a time of transition from childhood to adulthood is marked a change in the physical, psychological and psychosocial. In girls, puberty is marked by the onset of menstruation (menarche). In adolescent girls needed a good nutritional status in helping the growth of adolescents including menstrual cycle regularity. Young women who have less or more nutritional intake can cause reproductive dysfunction and impact on menstrual disorders. The aim of research to determine the relationship of nutritional status with menstrual cycle in young women at junior high school rural and urban area. Design research is an correlative method with cross sectional, population that all young women who met the inclusion criteria. This research sample 120 respondents belong to 60 respondent from rural area and 60 respondent from urban area which obtained by using purposive sampling technique. The instrument using questionnaire menstrual cycle and observation sheet measurement results of weight and height were performed. The results of the statistical test using Chi Square test at $95 \%$ significance level $(\alpha \leq 0.05)$, then it is obtained in the rural with value $p=0.401$ while in urban areas with value $p=0.203$. This means that the value of $p>\alpha(0.05)$. Thus that there is no significant relationship between nutritional status and the menstrual cycle in young girls at at junior high school rural and urban area. And also there is not differents some variables in this reseacrh. Advice for young women to better maintain nutritional status and maintain their reproductive health so that they become a regular menstrual cycle.

Keywords: Nutritional Status, Menstrual Cycles, Young Women.

\section{PENDAHULUAN}

Masa remaja (adolescence) merupakan masa transisi dari masa anak-anak menuju dewasa, yang ditandai dengan terjadinya perubahan-perubahan di dalam tubuh secara fisik, psikis, juga secara sosial. ${ }^{1}$ penduduk remaja di indonesia sudah mencapai 64 juta $(27,6 \%)$ dari total penduduk indonesia. Berdasarkan Pusat Data Dan Informasi Kementerian Kesehatan RI, hanya $15,3 \%$ dari total remaja putri yang mengerti tentang masalah gangguan menstruasi. ${ }^{1}$ 
Hal : $1-9$

Status gizi merupakan keadaan tubuh sebagai akibat konsumsi makanan dan penggunaan gizi. Selama ini telah diketahui bahwa wanita dengan status gizi kurang maupun lebih, dapat berisiko terjadinya gangguan siklus menstruasi. Penelitian yang dilakukan oleh Felicia di PSIK FK UNSRAT MANADO, menunjukan responden dengan status gizi kurus mengalami menstruasi tidak teratur sebanyak $66,7 \%$ sedangkan pada status gizi gemuk juga mengalami menstruasi tidak teratur sebanyak $81,8 \%{ }^{2}$

Kebutuhan gizi remaja relatif besar, karena remaja masih mengalami masa pertumbuhan. Remaja umumnya melakukan aktivitas fisik lebih tinggi dibandingkan dengan usia lainnya, sehingga diperlukan zat yang lebih banyak. Secara biologis kebutuhan gizi remaja sejalan dengan aktivitas yang dilakukannya. Remaja membutuhkan lebih banyak protein, vitamin, dan mineral. ${ }^{3}$

Banyak dampak yang akan dialami oleh remaja ketika mengalami malnutrisi, seperti pada remaja yang kurang gizi atau bertubuh kurus akan mempengaruhi reproduksi. Sedangkan pada remaja yang mengalami gizi lebih atau bertubuh gemuk akan berisiko terjadinya penyakit degenerative semakin tinggi, seperti hipertensi, diabetes melitus, penyakit jantung koroner dan lain-lain. ${ }^{6}$ Hampir $50 \%$ remaja tidak sarapan setiap paginya. Penelitian lain membuktikan masih banyak remaja (89\%) yang meyakini kalau sarapan memang penting, namun mereka yang sarapan secara teratur hanya $60 \%$. Berdasarkan penelitian yang dilakukan pebrina tentang siklus menstruasi pada siswi SMAN 12 Padang, menunjukkan bahwa dari 186 orang responden, yang mengalami siklus menstruasi tidak teratur sebanyak 57 orang $(30,6 \%)$. Hal ini disebabkan oleh berbagai faktor seperti memiliki status gizi yang tidak normal, melakukan program diet, melakukan aktivitas fisik yang berlebihan seperti atlet pelari dan atlet senam balet dan mengalami gangguan penyakit endokrin seperti diabetes millitus, hipotiroid, hipertiroid. ${ }^{4}$

Faktor gizi juga sangat penting dalam mendukung kesuburan karena fertilitas seseorang selain dipengaruhi oleh genetik, keturunan dan usia juga dipengaruhi oleh status gizinya. Body Mass Index (BMI) merupakan indikator yang paling sering digunakan dan praktis untuk mengukur status gizi pada orang dewasa. Berat badan dan perubahan pada berat badan yang melebihi berat badan normal atau kurang dari berat badan normal akan mempengaruhi pada pertumbuhan remaja. ${ }^{5}$

Menstruasi merupakan salah satu fisiologis seksual yang pertama kali terjadi pada masa pubertas seorang wanita. Periode menstruasi sangat penting dalam reproduksi. Periode ini biasanya terjadi setiap bulan yang dipengaruhi oleh hormon reproduksi baik itu estrogen maupun progesteron. Menstruasi yang terjadi secara reguler setiap bulan, akan membentuk yang namanya suatu siklus menstruasi. Terjadinya siklus menstruasi yang reguler merupakan penanda bahwa organ-organ reproduksi seorang wanita berfungsi secara baik. Satu siklus terhitung mulai dari hari pertama dalam satu periode hingga hari pertama pada periode berikutnya. Siklus menstruasi pada wanita normal berkisar antara 21 35 hari, dengan rata-rata durasi siklus ialah 28 hari. ${ }^{6}$

Dengan bertambahnya usia maka kadar FSH (Folicle Stimulating Hormone) meningkat, fase folikuler semakin pendek tapi kadar LH (Luteinizing Hormone) dan durasi fase luteal tidak berubah. Siklus menstruasi tetap teratur, tetapi panjang dan variabilitas siklus menstruasi keseluruhan mengalami penurunan. Saat kadar FSH meningkat dan fase folikuler semakin pendek, maka kadar estradiol meningkat lebih dini, menunjukkan bahwa kadar FSH yang lebih tinggi merangsang perkembangan folikel lebih cepat. ${ }^{7}$

Penelitian yang dilakukan Emillia juga menunjukkan adanya perbedaan signifikan panjang siklus menstruasi antara remaja putri di kota dan desa (SMP Negeri 6 Makassar dan SMP Negeri 11 Bulukumba). Adanya perbedaan tersebut disebabkan karena faktor nutrisi (konsumsi makanan sumber fitoestrogen) pada remaja putri, dimana remaja putri di kota lebih sering mengkonsumsi makanan sumber fitoestrogen dari pada remaja putri di desa. Konsumsi makanan sumber fitoestrogen yang ditemukan lebih tinggi pada remaja putri di kota menyebabkan siklus menstruasi pada remaja putri tersebut lebih teratur daripada remaja putri di desa. Hal ini dikarenakan makanan tersebut mengandung sumber fitoestrogen yang dapat mengganti estrogen yang kurang dalam tubuh. ${ }^{8}$

Oleh karena itu, ditetapkan tujuan penelitian ini adalah mengetahui untuk Hubungan Status Gizi Siswi SMP Di Pedesaan Dan Perkotaan Terhadap Pola Siklus Menstruasi. 
Hal : $1-9$

\section{METODE}

\subsection{Rancangan Penelitian}

Penelitian ini menggunakan metode koleratif, penelitian koleratif adalah penelitian dengan mencari hubungan antara dua variabel. Adapun pendekatan yang digunakan adalah cross sectional, dengan pengukuran variabel bebas dan terikat pada waktu yang bersamaan tanpa periode follow up. Rancangan penelitian ini digunakan untuk mencari hubungan status gizi dengan pola siklus menstruasi.

\subsection{Populasi dan Sampel}

\subsubsection{Populasi}

Populasi penelitian ini adalah remaja siswi SMP Kelas I dan II (13-15 tahun) di tiga sekolah yaitu SMP abulyatama, SMPN 1 kuta baro dan SMPN 1 banda aceh.

\subsubsection{Sampel}

Sampel adalah sebagian dari jumlah dan karakteristik yang dimiliki oleh populasi tersebut. Tehnik pengambilan sampel dalam penelitian ini dilakukan dengan menggunakan metode purposive sampling. Yaitu sampel yang diambil berdasarkan tujuan penelitian dengan cara menetapkan ciri-ciri khusus dan diharapkan mewakili dalam sampel. Dengan jumlah sampel keseluruhan 120 siswi, dengan rincian SMP abulyatama dan SMPN 1 kuta baro terdapat 60 siswi dengan kategori pedesaan dan SMPN 1 banda aceh terdapat 60 siswi dengan kategori perkotaan.

\subsection{Lokasi dan Waktu Penelitian}

\subsubsection{Lokasi Penelitian}

Lokasi penelitian berada di 3 Sekolah Menengah Pertama yang terletak di 2 daerah yang berbeda Banda Aceh dan Aceh Besar yaitu SMP 1 Banda Aceh, SMP Abulyatama dan SMP 1 Kuta Baro.

\subsubsection{Waktu Penelitian}

Waktu penelitian direncanakan pada tanggal 19-25 maret tahun 2019.

\subsection{Variabel Penelitian}

1. Variabel bebas adalah apabila variabel tersebut berubah akan mengakibatkan perubahan variabel lain. Variabel bebas dalam penelitian ini adalah status gizi.

2. Variabel terikat adalah variabel yang berubah akibat perubahan variabel bebas. Variabel terikat dalam penelitian ini adalah pola siklus menstruasi.

\subsection{Kriteria Inklusi dan Eksklusi}

1. Kriteria Inklusi

Kriteria inklusi dari penelitian ini adalah:
a. Remaja siswi SMP kelas I dan II
b. Anak yang bersedia menjadi subjek penelitian
c. Anak yang bersifat kooperatif saat penelitian

2. Kriteria Eksklusi

Kriteria eksklusi dari penelitian ini adalah:

a. Anak yang belum mengalami menstruasi

b. Anak yang tidak bersedia untuk sampel penelitian

\subsection{Pengumpulan Data}

\subsubsection{Cara Pengumpulan Data}

Data dikumpulkan melalui pengukuran berat badan, tinggi badan, lalu responden diwawancara dengan menggunakan checklist yaitu kuesioner.

\subsubsection{Cara Pengukuran}

Pengukuran berat badan menggunakan timbangan berat badan, pengukuran tinggi badan menggunakan microtoise, yang akan dilakukan langsung oleh peneliti terhadap responden.

\subsubsection{Pengolahan Data}

Pengolahan data dilakukan dengan beberapa tahap, antara lain:

1. Editing, yaitu melakukan pengecekan jawaban kuesioner di tempat secara langsung dan apabila ada kekurangan segera di lengkapi.

2. Coding, yaitu mengubah data dalam bentuk huruf menjadi angka dan memberikan kode untuk memudahkan analisa data.

3. Data entry, yaitu proses memasukkan data ke dalam komputer untuk dilakukan pengolahan data sesuai kriteria dengan menggunakan SPSS for windows. 
Hal : $1-9$

4. Cleaning, pengecekan kembali untuk mengoreksi apabila terdapat kesalahan dalam pengolahan data.

\subsubsection{Analisa Data}

a. Analisis Univariat

Analisis data univariat adalah untuk mengetahui hasil gambaran skrining pada variabelvariabel yang telah ditentukan dengan menggunakan kuesioner dan pengukuran pertumbuhan.

b. Analisis Inferensial

1. Uji Normalitas Data

Uji normalitas data dimaksudkan untuk menentukan normal tidaknya distribusi data penelitian, artinya apakah penyebarannya dalam populasi bersifat normal atau tidak normal. Normalitas data diuji dengan menggunakan pendekatan Kolmogorov-Smirnov. Data dinyatakan berdistribusi normal apabila nilai Sig $>0,05$. Sebaliknya, data berdistribusi tidak normal apabila nilai Sig $<0,05$.

\section{Uji Homogenitas Data}

Uji homogenitas data dimaksudkan untuk mengetahui perbedaan varians data sama atau homogen. Homogenitas data diuji dengan pendekatan Levene's Test. Data dinyatakan memiliki varians yang sama (homogen) jika nilai Sig $>0,05$. Sebaliknya, data dinyatakan memiliki varians tidak homogen jika nilai $\mathrm{Sig}<0,05$. c. Analisis Bivariat

1. Untuk mengetahui hubungan variabel bebas dan variabel terikat, yang hubungan status gizi dengan pola siklus menstruasi.

2. Uji Chi-Square

Uji chi-square digunakan karena variabel dependen dan independen merupakan variabel kategorik. Nilai yang digunakan adalah $p$ value, apabila nilai $p<0,05$ berati ada perbedaan antara keduanya. Uji chi square akan dilakukan dengan menggunakan SPSS.

Rumus :

$$
\begin{gathered}
x^{2}=\sum \frac{(O-E)^{2}}{E} \\
\mathrm{x}^{2} \quad=\text { nilai uji chi square } \\
\mathrm{O}(\text { observed }) \quad=\text { nilai hasil pengamatan } \\
\mathrm{E}(\text { expected })=\text { nilai ekspektasi }
\end{gathered}
$$
berikut :

Kriteria perbedaan ditetapkan berdasarkan $p$ value. Adapun kriterianya sebagai

1. Jika $p$ value $<0,05$ maka ada hubungan yang signifikan antara kedua variabel

2. Jika $p$ value $\geq 0,05$ maka tidak ada hubungan yang signifikan antara kedua variabel d. Pengujian Hipotesis

Pengujian hipotesis dilakukan menggunakan uji beda rata-rata atau uji-t (independent sample $t$ test). Perhitungan koefisien $\mathrm{t}$ pada independent sample $t$ test ini digunakan dengan program SPSS. Uji- $t$ yang dilakukan dalam penelitian ini adalah umur, berat badan, tinggi badan, dan BMI siswi. Uji- $t$ tentang hal tersebut dilihat dari perbedaan antara daerah perkotaan dengan pedesaan. Perhitungan dengan uji $t$ bertujuan untuk mengetahui perbedaan secara signifikan antara daerah perkotaan dengan pedesaan. Berikut penafsiran dari masing-masing Uji- $t$ tersebut:

Hipotesis nol $\left(\mathrm{H}_{0}\right)$ dan hipotesis alternatif $\left(\mathrm{H}_{\mathrm{a}}\right)$ yang merupakan hipotesis komparatif atau perbandingan dalam penelitian ini sebagai perbedaan secara signifikan baik yang ada di daerah perkotaan dengan pedesaan:

$\mathrm{H}_{0}$ : Tidak ada perbedaan signifikan antara siswi perkotaan dengan pedesaan yang dilihat berdasarkan umur, berat badan, tinggi badan dan BMI siswi.

$\mathrm{H}_{\mathrm{a}} \quad$ : Ada perbedaan signifikan antara siswi perkotaan dengan pedesaan yang dilihat berdasarkan umur, berat badan, tinggi badan dan BMI siswi. 
Vol. 6, No. 2 (2019)

$\mathcal{H a l}: 1-9$

III. HASIL

\subsection{Hasil Peneltian}

Dari hasil output spss dan pengujian hipotesis dari variabel status gizi dan pola siklus menstruasi baik pada siswi SMP di daerah pedesaan maupun siswi SMP di daerah perkotaan. Sampel yang digunakan dalam penelitian ini sebanyak 60 responden dari masing-masing SMP.

\subsubsection{Analisis Univariat}

Analisis deskriptif dilihat berdasarkan umur, berat badan, tinggi badan, dan body mass index siswi smp pedesaan dan smp perkotaan.

Tabel 3.1 Distribusi Frekuensi Berdasarkan Umur Siswi SMP Pedesaan dan SMP Perkotaan

\begin{tabular}{lcc}
\hline Variabel & Frekuensi (F) & Persentase (\%) \\
\hline Umur Siswi SMP Pedesaan & 4 & \\
a. 13 Tahun & 36 & 6.7 \\
b. 14 Tahun & 20 & 60 \\
c. 15 Tahun & 60 & 33.3 \\
\hline Jumlah & & 100.0 \\
\hline Umur Siswi SMP Perkotaan & 11 & \\
a. 13 Tahun & 34 & 18.3 \\
b. 14 Tahun & 15 & 56.7 \\
c. 15 Tahun & 60 & 25.0 \\
\hline Jumlah & & 100.0 \\
\hline
\end{tabular}

Berdasarkan tabel 3.1. Memperlihatkan distribusi umur responden yang bahwa, siswi SMP pedesaan sebagian besar berumur 14 tahun sebanyak $36(60 \%)$ orang dan paling sedikit berumur 13 tahun sebanyak $4(6.7 \%)$ orang. Sedangkan siswi smp perkotaan sebagian besar berumur 14 tahun sebanyak $34(56,7 \%)$ orang dan paling sedikit berumur 13 tahun sebanyak $11(18,3 \%)$ orang.

Tabel 3.2 Distribusi Frekuensi Berdasarkan Berat Badan, Tinggi Badan, dan BMI Siswi SMP Pedesaan

\begin{tabular}{lccc}
\hline \multicolumn{1}{c}{ Variabel } & Minimum & Maksimum & Mean \pm SD \\
\hline Berat Badan Siswi SMP Pedesaan & 34 & 70 & $43.67 \pm 8.01$ \\
\hline Tinggi Badan Siswi SMP Pedesaan & 136 & 161 & $149.27 \pm 6.493$ \\
\hline $\begin{array}{l}\text { Body Mass Index Siswi SMP } \\
\text { Pedesaan }\end{array}$ & 13.26 & 29.13 & $19.23 \pm 3.30$ \\
\hline
\end{tabular}

Tabel 3.3 Distribusi Frekuensi Berdasarkan Berat Badan, Tinggi Badan, dan BMI Siswi SMP Perkotaan

\begin{tabular}{|c|c|c|c|}
\hline Variabel & Minimum & Maksimum & Mean \pm SD \\
\hline Berat Badan Siswi SMP Perkotaan & 30 & 78 & $46.03 \pm 10.94$ \\
\hline $\begin{array}{l}\text { Tinggi Badan } \\
\text { Perkotaan }\end{array}$ & 134 & 170 & $150.77 \pm 6.66$ \\
\hline $\begin{array}{l}\text { Body Mass Index Siswi SMP } \\
\text { Perkotaan }\end{array}$ & 14 & 35 & $20.08 \pm 4.49$ \\
\hline
\end{tabular}

Berdasarkan tabel 3.2 dan 3.3 didapatkan bahwa berat badan, tinggi badan dan BMI siswi SMP pedesaan dan perkotaan tidak jauh berbeda, dapat diketahui dari nilai minimum-maksimum serta mean dan standar deviasi yang diperoleh dari masing-masing variabel. 
Hal : $1-9$

\section{Tabel 3.4 Distribusi Frekuensi Berdasarkan Status Gizi Dan Siklus Menstruasi Siswi SMP Pedesaan dan SMP Perkotaan}

\begin{tabular}{lcc}
\hline Variabel & Frekuensi (F) & Persentase (\%) \\
\hline Status Gizi Siswi SMP Pedesaan & 26 & 43.3 \\
a. Gizi Kurus & 27 & 45 \\
b. Gizi Normal & 4 & 6.7 \\
c. Gizi Lebih & 3 & 5 \\
d. Obese I & & \\
\hline
\end{tabular}

Status Gizi Siswi SMP Perkotaan

$\begin{array}{lcc}\text { a. Gizi Kurus } & 23 & 38.3 \\ \text { b. Gizi Normal } & 22 & 36.7 \\ \text { c. Gizi Lebih } & 10 & 16.7 \\ \text { d. Obese I } & 4 & 6.7 \\ \text { e. Obese II } & 1 & 1,7\end{array}$

\begin{tabular}{lcc}
\hline \multicolumn{2}{l}{ Siklus Menstruasi Siswi SMP Pedesaan } & \\
a. Teratur & 45 & 75.0 \\
b. Tidak Teratur & 15 & 25.0 \\
\hline Siklus Menstruasi Siswi SMP Perkotaan & 75.0 \\
a. Teratur & 45 & 25.0 \\
b. Tidak Teratur & 15 & \\
\hline
\end{tabular}

Berdasarkan pada tabel. 3.4 diatas dapat diketahui distribusi status gizi dan siklus menstruasi dari masing-masing siswi SMP pedesaan dan SMP perkotaan. Sebagian besar siswi SMP mempunyai status gizi kurus siswi smp pedesaan yaitu 26 (43,3\%) orang dan status gizi kurus siswi SMP perkotaan 23 (38.3\%), status gizi normal masing-masing 27 (45\%) dan 22 (36.7\%), sedangkan status Obese I dan Obese II memperoleh sedikit yaitu pada pedesaan Obeses I adalah 3 (5\%) dan perkotaan yaitu 4 (6.7\%). Sedangkan Obese II adalah $1(1,7 \%)$ pada perkotaan.

Pola siklus menstruasi siswa SMP pedesaan dan perkotaan, dari 60 responden yang mempunyai siklus menstruasi teratur sebanyak $45(75.0 \%)$ siswi, sedangkan siswi yang mempunyai siklus menstruasi tidak teratur sebanyak 15 (25.0\%) siswi. Berdasarkan hasil tersebut dapat disimpulkan bahwa secara umum pola siklus menstruasi siswi SMP pedesaan dan perkotaan memiliki pola siklus yang sama.

\subsubsection{Analisis Bivariat}

Untuk mengetahui hubungan variabel bebas dan variabel terikat, yaitu hubungan status gizi dengan pola siklus menstruasi.

Tabel 3.5 Hubungan Status Gizi Dengan Siklus Menstruasi

Pada Siswa SMP di Pedesaan

\begin{tabular}{|c|c|c|c|c|c|c|c|}
\hline \multirow[t]{2}{*}{ 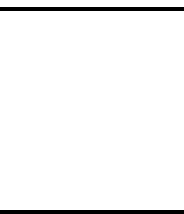 } & \multirow[t]{2}{*}{ Variabel } & & \multicolumn{2}{|c|}{$\begin{array}{c}\text { Pola Siklus } \\
\text { Menstruasi Siswi } \\
\text { SMP Desa }\end{array}$} & \multirow[t]{2}{*}{ Total } & \multirow[t]{2}{*}{$\begin{array}{c}\text { Koefisien } \\
\text { Kontingensi }\end{array}$} & \multirow[t]{2}{*}{ Sig } \\
\hline & & & Teratur & $\begin{array}{c}\text { Tidak } \\
\text { Teratur }\end{array}$ & & & \\
\hline \multirow{4}{*}{$\begin{array}{l}\text { Status } \\
\text { Gizi Siswi } \\
\text { SMP Desa }\end{array}$} & Gizi Kurus & Jumlah & 20 & 6 & 26 & \multirow{5}{*}{0.216} & \multirow{5}{*}{0.401} \\
\hline & Gizi Normal & Jumlah & 21 & 6 & 27 & & \\
\hline & Gizi Lebih & Jumlah & 3 & 1 & 4 & & \\
\hline & Obese I & & 1 & 2 & 3 & & \\
\hline & otal & Total & 45 & 15 & 60 & & \\
\hline
\end{tabular}

Berdasarkan tabel 3.5 di atas, responden yang memiliki gizi kurus mempunyai pola siklus menstruasi yang teratur sebanyak 20 dari 26 siswi, gizi normal sebanyak 21 dari 27 siswi, gizi lebih sebanyak 3 dari 4 sisiwi dan Obese I yaitu 1 dari 3 siswi . Dari hasil uji statistik chi-square didapatkan nilai $\mathrm{p}=0.401$ hal ini menunjukkan bahwa tidak terdapat hubungan yang bermakna status gizi dengan pola siklus menstruasi pada siswi SMP di 
Hal : $1-9$

pedesaan. Bila ditinjau seberapa besar hubungannya dapat diketahui dari nilai koefisien kontingensi sebesar 0.216 atau hubungannya sangat lemah.

Tabel 3.6 Hubungan Status Gizi Dengan Siklus Menstruasi Pada Siswa SMP Di Perkotaan

\begin{tabular}{|c|c|c|c|c|c|c|c|}
\hline & \multirow[t]{2}{*}{ Variabel } & & \multicolumn{2}{|c|}{$\begin{array}{l}\text { Pola Siklus Menstruasi } \\
\text { Siswi SMP Kota }\end{array}$} & \multirow[t]{2}{*}{ Total } & \multirow[t]{2}{*}{$\begin{array}{r}\text { Koefisien } \\
\text { Kontingensi }\end{array}$} & \multirow[t]{2}{*}{ Sig } \\
\hline & & & Teratur & Tidak Teratur & & & \\
\hline & Gizi Kurus & Jumlah & 15 & 8 & 23 & \multirow{6}{*}{0.300} & \multirow{6}{*}{0.203} \\
\hline Status & Gizi Normal & Jumlah & 20 & 2 & 22 & & \\
\hline Gizi Siswi & Gizi Lebih & Jumlah & 7 & 3 & 10 & & \\
\hline \multirow[t]{3}{*}{ SMP Kota } & Obese I & & 2 & 2 & 4 & & \\
\hline & Obese II & & 1 & 0 & 1 & & \\
\hline & Total & Total & 45 & 15 & 60 & & \\
\hline
\end{tabular}

Berdasarkan tabel 3.6 di atas, responden yang memiliki gizi kurus mempunyai pola siklus menstruasi yang teratur sebanyak 15 dari 23 siswi, gizi normal sebanyak 20 dari 22 siswi, gizi lebih sebanyak 7 dari 10 siswi, Obese I yaitu 2 dari 4 siswi dan Obese II yaitu 1 dari 1 siswi. Dari hasil uji statistik chi-square didapatkan nilai $p=0.203$. Hal ini menunjukkan bahwa tidak terdapat hubungan yang bermakna status gizi dengan pola siklus menstruasi pada siswa SMP di perkotaan. Bila ditinjau seberapa besar hubungannya dapat diketahui dari nilai koefisien kontingensi sebesar 0.300 atau hubungannya rendah.

\section{PEMBAHASAN}

\subsection{Status Gizi di Pedesaan}

Berdasarkan distribusi frekuensi status gizi yang diperoleh dari tinggi badan dan berat badan lalu di kategorikan dengan menggunakan BMI, menunjukkan bahwa dari 60 siswi di daerah pedesaan terdapat lebih banyak yang mengalami gizi normal yaitu 27 ( $45 \%$ ) dari pada gizi kurus yaitu 26 (43.3\%) dan gizi yang terendah adalah obese i yaitu dengan nilai $3(5 \%)$.

\subsection{Status Gizi di Perkotaan}

Berdasarkan distribusi frekuensi status gizi yang diperoleh dari tinggi badan dan berat badan lalu di kategorikan dengan menggunakan BMI, menunjukkan bahwa dari 60 siswi di daerah perkotaan terdapat lebih banyak yang mengalami gizi kurus dengan jumlah siswi $23(38,3 \%)$ dari pada gizi normal dengan jumlah siswi 22 ( $36 \%)$ dan gizi yang terendah adalah obese II dengan nilai $1(1,7 \%)$.

Kebiasaan pada remaja yaitu mengonsumsi kudapan yang berlebihan sehingga hampir keseluruhan dari jumlah konsumsinya sehari-hari didapat dari kudapan tersebut. Seperti lingkungan sekolah, jika kantin sekolah hanya menyediakan makanan-makanan yang merupakan sumber karbohidrat saja, akan besar sekali pengaruh kantin ini terhadap terjadinya kesalahan gizi remaja. ${ }^{9}$

\subsection{Pola Siklus Menstruasi Di Pedesaan}

Dari hasil penelitian yang telah dilakukan pada 60 siswi SMP di pedesaan diperoleh bahwa siklus menstruasi lebih banyak mengalami teratur yaitu sebesar $45(75 \%)$ siswi dan yang tidak tertus sebanyak 15 (25\%) siswi. Oleh siswi SMP yadari 23 siswi. Penelitian ini sejalan dengan yang dilakukan Supratikyo pada siswi SMP Ma'hadul Qur'an Sukorejo Situbondo responden mengalami siklus menstruasi yang normal yaitu sebanyak 64 responden atau $53.3 \%$, dan hampir setengah dari responden atau sebanyak 56 responden $(46.7 \%)$ mengalami siklus menstruasi yang tidak normal. ${ }^{10}$

\subsection{Pola Siklus Menstruasi Di Perkotaan}

Berdasarkan distribusi frekuensi di perkotaan, sama halnya dengan yang di pedesaan, dari 60 siswi SMP di pedesaan diperoleh bahwa siklus menstruasi teratur sebanyak $45(75 \%)$ dan tidak teratur $15(25 \%)$. Penelitian ini sejalan dengan Yulianti di MTSN Lampung dari 62 siswi terdapat $39(62,9 \%)$ siswi mengalami mentruasi teratur. Penelitian menggunakan observasional analitik dengan pendekatan crosss sectional. Hasil uji statistik chi square dengan derajat kepercayaan (ci) $95 \%$ dan nilai $\alpha(0,05) .{ }^{11}$

\subsection{Hubungan Status Gizi dengan Pola Siklus Menstruasi di Pedesaan}


Hal : 1-9

Dari hasil analisis bivariat tidak menunjukkan adanya hubungan yang signifikan atau hubungannya sangat rendah pada daerah perkotaan dengan nilai $\mathrm{p}=0.401$ dan dilihat dari koefisien kontingensi sebesar 0.216 .

Penelitian ini sejalan dengan yang dilakukan Oktaviani, hasil uji statistik menggunakan chi-square tidak ditemukan adanya hubungan yang bermakna antara gizi dengan gangguan siklus menstruasi $(p=0,470)$. Persamaan ini karena data yang diperoleh dan dianalisis dengan komputer berupa uji analisis chi-square dengan tingkat pemaknaan $p$ $<0,05$ sampel yang digunakan yaitu sebanyak 61 sampel yang merupakan siswi SMPN 1 Pekanbaru. Populasi memiliki persentase lemak tubuh dalam dari hasil analisis imt diperoleh $62,3 \%$ remaja putri dengan indeks massa tubuh normal, $32,8 \%$ kurus dan $4,9 \%$ gemuk. Hal tersebut serupa dengan penelitian ini yaitu didapatkan responden dengan BMI gizi kurus lebih banyak yang mengalami ketidakteraturan siklus menstruasi dibandingkan responden gizi lebih dan normal. Ketidakteraturan siklus menstruasi juga dipengaruhi oleh onset menstruasi diatas umur 14 tahun, tingkat depresi, paritas dan lain lain. Penelitian ini hanya meneliti pengaruh lemak terhadap siklus menstruasi tetapi tidak melihat tingkat depresi serta onset menstruasi. $^{12}$

\subsection{Hubungan Status Gizi dengan Pola Siklus Menstruasi di Perkotaan}

Berdasarkan dari analisis bivariat tidak menunjukkan adanya hubungan yang signifikan diaerah perkotaan dengan nilai sebesar $p=0.203$ atau hubungannya sangat rendah dengan melihat koefisien kontingensi dengan nilai 0.300 .

Penelitian ini tidak sebanding dengan penelitian yang dilakukan oleh Irmayanti pada siswi SMPN 17 kota jambi. Dari 74 responden menunjukkan dari 43 siswi yang tidak obesitas diperoleh sebanyak $13(30,2 \%)$ siswi yang memiliki siklus menstruasi pendek, diketahui $27(62,8 \%)$ siswi memiliki siklus menstruasi normal, dan $3(7,0 \%)$ siswi memiliki siklus menstruasi panjang. Dari 31 siswi yang obesitas $6(19,4 \%)$ memiliki siklus menstruasi pendek, $4(12,9 \%)$ memiliki siklus menstruasi normal, dan $21(67,7 \%)$ memiliki siklus menstruasi panjang. Berdasarkan hasil analisa yang menggunakan uji statistic chi-square diperoleh nilai $p$-value $=0,003$ dengan derajat kemaknaan 0,05 , yang berarti nilai $p$-value $<$ 0,05 , maka hoditolak atau dapat disimpulkan ada hubungan yang signifikan antara imt dengan siklus menstruasi di SMPN 17 kota Jambi tahun 2012. Hasil penelitian ini dapat terlihat bahwa apabila remaja memiliki asupan gizi yang baik dengan stabilitas emosi yang baik disertai gaya hidup dan pola makan yang baik bisa membuat kerja hipotalamus menjadi baik sehingga bisa memproduksi hormon-hormon yang dibutuhkan tubuh terutama hormon reproduksi, sehingga siklus menstruasi bisa menjadi teratur. Perbedaan pada penelitian terletak pada jenis rancangan peneltian dan populasi yang diambil karena pada penelitian ini menggunakan metode teknik stratified random sampling yaitu metode yang menetapkan tingkatan pada populasi yang sesuai dengan tujuan penelitian. ${ }^{9}$

\section{KESIMPULAN}

Berdasarkan frekuensi status gizi siswi SMP daerah pedesaan lebih banyak mengalami gizi normal dibandingkan gizi kurus, lebih, Obese I dan Obese II. Sedangkan frekuensi status gizi siswi SMP daerah perkotaan lebih banyak mengalami gizi kurus dibandingkan gizi normal, lebih, Obese I dan Obese II. Frekuensi siklus menstruasi siswi SMP di daerah pedesaan lebih banyak mengalami siklus teratur. Sedangkan frekuensi siklus menstruasi siswi SMP di daerah perkotaan juga lebih banyak mengalami siklus mentruasi teratur. Dalam penelitian ini tidak terdapat hubungan yang signifikan antara status gizi dan siklus menstruasi siswi SMP yang sekolah di daerah pedesaan. Dengan hasil nilai $p=0.467$

. Bila ditinjau seberapa besar hubungannya dapat diketahui dari nilai koefisien kontingensi sebesar 0.157 atau hubungannya sangat lemah. Adapun siswi SMP di daerah perkotaan juga tidak ada hubungan status gizi dengan siklus menstrausi dengan nilai $p=0.095$. Bila ditinjau seberapa besar hubungannya dapat diketahui dari nilai koefisien kontingensi sebesar 0.270 atau hubungannya rendah. Adapun dalam Uji T sebagai parametrik tidak terdapat perbedaan secara signifikan pada berat badan, tinggi badan dan siklus menstruasi, tetapi ada perbedaan secara signifikan pada BMI di pedesaan dan perkotaan. Sedangkan secara non parametrik dengan Mann-Whitney $U$ tidak terdapat perbedaan secara signifikan pada umur siswa pedesaan dan perkotaan. 
Hal : $1-9$

\section{SARAN}

Bagi tenaga kesehatan diharapkan dapat lebih memahami tentang kesehatan reproduksi remaja khususnya siklus menstruasi dengan cara membaca buku atau mencari info yang up-date dari berbagai sumber sehingga dapat memberi solusi yang tepat apabila menemui kasus ketidakteraturan siklus menstruasi yang tidak hanya dipengaruhi oleh stress atau psikis saja tetapi juga faktor lainnya. Remaja dapat lebih memperhatikan asupan makanan yang sehat dan tidak melewatkan waktu makan utama sehingga memenuhi kebutuhan sehari yaitu $2.125 \mathrm{kkal}$ dan kecukupan asupan zat gizi makro dapat terpenuhi. Remaja diharapkan lebih memperhatikan pola makan dan jenis pilihan makanan sehingga mencapai berat badan ideal dan status gizi normal. Menghindari dan mengurangi faktorfaktor penyebab stres, serta diharapkan remaja mencatat tanggal menstruasi setiap bulannya agar dapat diketahui siklus menstruasi termasuk normal atau tidak normal. Bagi peneliti diharapkan melakukan penelitian dengan mencari faktor-faktor yang mempengaruhi status gizi terhadap pola siklus menstruasi.

\section{UCAPAN TERIMA KASIH}

Alhamdulillah rasa syukur kepada Allah SWT. Penulis menyampaikan ucapan terima kasih yang teristimewa kepada ibu dr. Dewi Karlina Rusly Sp.OG dan bapak Rizarullah M.Si selaku pembimbing yang telah mengoreksi dan membimbing dengan sangat baik, penuh kesabaran, serta ketelitian. Ucapan terima kasih kepada yang tercinta orang tua yaitu ayahanda $\mathrm{H}$. Amiruddin Siregar dan Ibunda Hj. Nurmawati Pane S.Pd., M.Pd, serta kakakkakak penulis drg. Syafrida Henni Siregar, Irma Hadiahni Putri Siregar Am.Keb dan dr. Rima Yanti Siregar, serta abang penulis yaitu dr. Rasyid Sulaiman M.Kes, dan dr. Nurdin Yusuf Siregar M.Kes. Serta seluruh keluarga besar yang selalu memberikan dukungan baik secara finansial maupun moril, perhatian dan doa bagi keberhasilan penulis.

\section{DAFTAR PUSTAKA}

1. Kementrian Kesehatan RI. Infodation Pusat Data Dan Informasi Kesehatan RI Situasi Kesehatan Reproduksi Remaja. Jakarta.2013;1-2

2. Felicia. Stres dan Mekanisme Koping Terhadap Gangguan Siklus Menstruasi Pada Remaja Putri di PSIK UNSRAT MANADO. Jurnal Keperawatan Unsrat. 2015;3(1):17.

3. Melia P. Hubungan Status Gizi Dengan Keteraturan Siklus Menstruasi Pada Siswi Remaja Di SMA N 12 Padang Tahun 2015. Journal Medica Saintika. 2016;7:35-45. http:jurnal.syedzasaintika.ac.id.

4. Pebrina M. Hubungan Status Gizi Dengan Keteraturan Siklus Mentruasi. Jurnal Fk Unsrat. 2016;2-3.

5. Vilda A. Karakter Gizi Remaja Putri. Jurnal Kesehatan Remaja Urban dan Rural di Provinsi Jawa Tengah. 2015;43-52.

6. Kandou PRD, Tombokan KC, Pangemanan DHC. Hubungan Antara Stres dan Pola Siklus Menstruasi Pada Mahasiswa Kepaniteraan Klinik Madya ( co-assistant ). Jurnal Akademi Keperawatan Telanai Bhakti Jambi. 2017;5-6.

7. Jannah M. Remaja dan Tugas-Tugas Perkembanganya. Journal Psikoislamedia. 2016:1-1.

8. Emillia SL. Perbandingan Usia Menars dan Pola Siklus Menstruasi Antara Remaja Putri di Kota dan Desa (SMP Negeri 6 Makassar dan SMP Negeri 11 Bulukumba). Jurnal UNHAS. 2013;3-4.

9. Hutagaol E, Kundre R, Studi P, et al. Hubungan Status Gizi Dengan Siklus Menstruasi Pada Remaja Putri di Psik Fk Unsrat Manado. 2015;3.

10. Irmayanti V. Hubungan Indeks Massa Tubuh (IMT) Terhadap Siklus Menstruasi Pada Remaja Putri di SMPN 17 Kota Jambi Tahun 2012. Akad Keperawatan Telanai Bhakti Jambi. 2013;2(1):1.

11. Wahyuni Y, Dewi R. Gangguan siklus menstruasi kaitannya dengan asupan zat gizi pada remaja vegetarian.E-journal Undip. 2018;6(2):76-81.

12. Supratikyo. Hubungan Status Gizi Dengan Siklus Menstruasi Remaja Putri Ma'hadul Qur'an Sukorejo Situbondo. Jurnal Ibrahimy. 2016;3(1). 